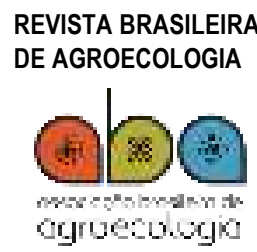

ISSN: 1980-9735

DOI: $10.33240 /$ rba.v15i4.23271

Vol. 15 | No 4 Esp. | p.04-17 | 2020

ARTIGO

\title{
PLANTAS MEDICINAIS DOS POVOS KAIOWÁ E GUARANI COMO POSSÍVEL PRÁTICA COMPLEMENTAR NO ENFRENTAMENTO DOS SINTOMAS DA COVID-19: CONHECIMENTO TRADICIONAL COMO
}

'Mestranda do Programa de Pós Graduacão em Educação e Territorialidade, da Faculdade Intercultural Indígena (FAIND) Universidade Federal da Grande Dourados. E-mail: soniapavaogk@gmail.com

2 Mestranda do Programa de Pós Graduação em Educação e Territorialidade, da Faculdade Intercultural Indígena (FAIND) Universidade Federal da Grande Dourados. E-mail: lopesinair@gmail.com

${ }^{3}$ Mestre pelo Programa de Pós Graduação em Biologia Geral/Bioprospecção, da Faculdade de Ciências Biológicas e Ambientais (FCBA), Universidade Federal da Grande Dourados.

E-mail: kellnatalice@outlook.com

${ }_{4}$ Mestrando pelo Programa de Pós Graduação Entomologia e Conservação da Biodiversidade, da Faculdade de Ciências Biológicas e Ambientais (FCBA), Universidade Federal da Grande Dourados.

E-mail: marildodasilvape-

dro228@gmail.com

5 Professora da Faculdade Intercultural Indígena (FAIND), Universidade Federal da Grande Dourados. E-mail: lauragisloti@gmail.com

Recebido em: 15/06/2020

Aceito para publicação em: 31/08/2020

Correspondência para: soniapavaogk@gmail.com

\author{
ARMA CONTRA A PANDEMIA \\ Medicinal plants of the kaiowá and guarani peoples as a possible complementary \\ practice in treating the symptoms of Covid-19: traditional knowledge as a weapon \\ against the pandemic
}

-

Sônia Pavão', Inair Lopes², Kellen Natalice Vilharva³, Marildo da Silva Pedro ${ }^{4}$ L Laura Jane Gisloti ${ }^{5}$

\section{RESUMO}

Com base na análise da literatura disponível, realizamos uma leitura crítica das evidências disponíveis para fornecer um bom cenário dos estudos etnobotânicos para com os povos Kaiowá e Guarani que listam plantas usadas tradicionalmente no trato do sistema respiratório, que é o principal sistema acometido pela Covid-19 e, assim, confeccionamos um levantamento de dados com informações sobre as espécies encontradas. Encontramos sete trabalhos sobre plantas medicinais utilizadas por esses povos para o tratamento de sintomas gripais, com um total de 31 espécies de angiospermas de uso terapêutico relacionado ao sistema respiratório, incluídas em 27 gêneros e 14 famílias. De todas as catalogadas, 27 (87,1\%) são plantas nativas dos domínios fitogeográficos brasileiros, enquanto quatro (12,9\%) são espécies exóticas. As espécies que foram mais citadas entre os sete trabalhos analisados foram Cedrela fissilis (Fabaceae) e Moquiniastrum polymorphum (Amaranthaceae). Concluímos que o conhecimento tradicional Kaiowá e Guarani a respeito das plantas medicinais pode ser considerado uma ferramenta possível no enfrentamento desta pandemia.

Palavras-chave: Coronavírus. Etnobotânica. Indígena. Medicina Tradicional.

\section{ABSTRACT}

Based on the analysis of the available literature, we performed a critical reading of the available evidence to provide a good scenario for ethnobotanical studies with the Kaiowa and Guarani peoples who list plants traditionally used to treat the respiratory system, which is the main system affected by Covid- 19 and, thus, we made a data survey with information about the species found. We found seven studies on medicinal plants used by these peoples for the treatment of flu-like symptoms, with a total of 31 species of angiosperms for therapeutic use related to the respiratory system, included in 27 genera and 14 families. Of all cataloged, 27 (87.1\%) are native plants from the Brazilian phytogeographic domains, while four (12.9\%) are exotic species. The species that were most cited among the seven studies analyzed were Cedrela fissilis (Fabaceae) and Moquiniastrum polymorphum (Amaranthaceae). We conclude that the traditional Kaiowá and Guarani knowledge about medicinal plants can be considered a possible tool to face this pandemic.

Keywords: Coronavirus. Ethnobotany. Indigenous. Traditional Medicine. 
Introdução

Os povos indígenas vivem o paradoxo de terem que sobreviver às epidemias pelas quais não foram responsáveis. Desde a invasão do Império Português, que imediatamente trouxe a varíola, a gripe e o sarampo e que, de fato, foi fator fundamental para ocasionar um colapso em diversas sociedades ameríndias, esses povos resistem ao etnocídio perpetrado desde a invasão (LEVI-STRAUSS, 1955; RIBEIRO, 1956, 1982; CASTRO, 2002).

Dessa forma, além de resistir a outros "vírus" sociais, como a necropolítica, o colonialismo, a escravidão e o racismo como estrutura de poder e forma de controle (MBEMBE, 2018), as epidemias estrangeiras têm sido constantes e causam bastante desequilíbrio entre as coletividades indígenas. Embarcações europeias trouxeram o vírus do sarampo, da varíola e da gripe para indígenas americanos. Essas três doenças se espalharam pelos nativos das Américas, invadiram o litoral e avançaram pelos caminhos que levavam ao interior do continente. A varíola dizimou os astecas e o vírus da gripe, desconhecido dos indígenas, ocasionou epidemias devastadoras. Estimativas acreditam que mais de 90\% da população indígena morreu pelas doenças trazidas pelos europeus (GUERRA, 1988; RAMOS, 1993; ALMEIDA e NÖTZOLD, 2010; UJVARI, 2008).

Do mesmo modo, as comunidades rurais e indígenas de todo o mundo foram expostas à intrusão de empresas extrativas em seus territórios, que, de acordo com a ganância, têm modificado e destruído ecossistemas inteiros, gerando impactos irreversíveis (SHIVA, 2001, 2003; GONÇALVES, 2006; KRENAK, 2015). Novas investigações científicas corroboram a relação entre essa destruição e novas mutações de vírus, devido à superlotação de várias espécies de animais em espaços confinados, devido ao desmatamento ou contaminação de rios e solos. A história do Ebola, da gripe aviária, da febre do Vale do Rift, da febre do Nilo Ocidental, do Zika Vírus e agora do Covid-19, certamente está relacionada a essas alterações nos ecossistemas (CHUA et al., 2002; DUARTE et al., 2004; WOLFE et al., 2005; SEHGAL, 2010; RULLI et al., 2017; RUIZ-SAENZ et al., 2019; ELLWANGER et al., 2020; ZOA-ASSOUMOU et al., 2020).

A pandemia do novo coronavírus, intitulado Sars-CoV-2 e causador da doença denominada Covid-19, nos levou a uma quarentena planetária para evitar mais infecções (CUCINOTTA e VANELLI, 2020; LANA et al., 2020), às quais nossos sistemas de saúde não resistiram e, embora as populações indígenas sejam as menos expostas, são muito vulneráveis para esse contexto. Portanto, a Covid-19 se converteu em uma ameaça séria para os povos indígena e no Brasil, nas regiões do interior do país, os sistemas de saúde estão disponíveis com menos capacidade desde antes da demanda de pacientes infectados pelo vírus. O rápido ritmo de contágio desse novo invasor acende o alerta diante da vulnerabilidade desses povos, que têm modo de vida coletivo mais suscetível à propagação da doença. Outro complicador é a dificuldade de acesso ao tratamento em casos graves, o que aumenta o risco de genocídio de comunidades nativas, semelhantes aos registrados em epidemias ao longo da história (MARANHÃO, 2020).

Os Guarani são falantes da língua guarani pertencente ao tronco linguístico tupi-guarani com variações étnico-culturais dialetais. No Brasil encontram-se subdivididos em três povos: Guarani Ñandeva, Guarani Mby'a e Guarani Kaiowá. Esta pesquisa se refere aos Guarani Kaiowá e aos Guarani Ñandeva, segunda maior coletividade indígena do Brasil, precariamente territorializados no sudoeste do estado de Mato Grosso do Sul, os quais se autodenominam Kaiowá e Guarani ou Guarani e Kaiowá (BENITES, 2014).

A população Kaiowá e Guarani é superior a 50 mil indivíduos e está distribuída em oito reservas, além de quatorze terras indígenas, totalizando 22 áreas indígenas em uma área total de $182,97 \mathrm{~km}^{2}$. Em áreas de reserva indígena o acesso ao Sistema Único de Saúde (SUS) é uma realidade, no entanto, em áreas não demarcadas a situação é diferente e o acesso aos serviços de saúde é bastante limitado (PEREIRA, 2016).

Em Mato Grosso do Sul, a situação pungente dos Kaiowa e Guarani frente ao avanço da Covid-19 não tem sido diferente dos demais povos indígenas. Inúmeras entidades ligadas ao poder público e à sociedade civil tem vindo a público demonstrar imensa preocupação com o aumento exponencial dos 
casos registrados entre os Kaiowá e Guarani, além de responsabilizar os órgãos de Saúde Estadual e Federal, pelo começo do que pode se tornar uma tragédia amplamente anunciada (CIMI, 2020; CISCATI, 2020).

Para os Kaiowá e Guarani, essa nova realidade ocasionada pela pandemia tem se somado à ameaça constante da precarização territorial, que tem feito com que esses povos travem uma batalha incansável contra o roubo de suas terras tradicionais e contra o agronegócio imperante na região, fazendo com que a luta em defesa de seus territórios seja marcada por estratégias complexas baseada na valorização e manutenção de seus conhecimentos tradicionais (VALIENTE, 2019; BENITES, 2020). Como são povos intrinsecamente ligados a áreas de mata, suas territorialidades e cosmopolíticas constituem-se de um universo composto de múltiplos patamares profundamente inter-relacionados a dois eixos: a terra boa ("yvy porã") e a mata ("ka'aguy ygua") (nas línguas kaiowá e guarani), de forma que esses eixos fundamentam e alicerçam a base do conhecimento tradicional desses povos (BRAND, 2003; PEREIRA, 2014; MOTA, 2015).

As plantas medicinais compõem uma gama de grande importância cosmológica, ecológica e social para esses povos, de forma que inúmeros autores concordam com a importância desse tema para os Kaiowá e Guarani (MELIÀ, 1997; BRAND, 2001, 2003; BUENO et al., 2005, COLMAN, 2007; OLIVEIRA, 2007; VIETTA, 2007; SERAGUZA, 2013; BENITES, 2014; PEREIRA, 2014, 2016).

Nesse contexto, pensar a construção do conhecimento acadêmico e cientifico pautada na incorporação de conhecimentos específicos de populações tradicionais é uma proposta de concepção de construção de conhecimento à oposta à ciência clássica, aquela que defende uma neutralidade que não existe e, assim, acaba por ser incapaz de propor estratégias reais para o enfrentamento frente às crises. Nessa linha, evidenciar a importância da construção do conhecimento pautado em uma ciência cidadã, que considere o papel dos sujeitos e das sujeitas nos seus territórios, bem como que reconheça a natureza, também, como sujeita de direitos (SHIVA, 2003; KRENAK, 2017; SANTOS, 2018).

A Etnobiologia vem se destacando como ciência multi, inter e transdisciplinar, que se debruça sobre as diversas dimensões das percepções culturais das relações humanos/natureza. Relacionando as diferentes formas em que o conhecimento sobre o mundo natural está organizado, a Etnobiologia oferece um tipo de relativismo pelo qual é possível reconhecer outros modelos de convivência com a natureza que, não necessariamente, sejam baseados no racionalismo e no pragmatismo da ciência vigente patriarcal, branca, ocidental e colonialista (SHIVA, 2003; SANTOS, 2015). Em paralelo, a Etnobiologia tem o potencial de atuar como mediadora entre as diferentes culturas ao assumir seu papel como componente dedicado ao entendimento, compreensão, apoio e respeito mútuo entre os povos (POSEY, 1987).

Assim, a faceta da Etnobiologia a ser tratada neste estudo denomina-se Etnobotânica, que se propõe a estudar como sistemas dinâmicos as interações entre as sociedades humanas e as plantas, de forma que o bojo dessa ciência seja pautada à partir do estudo das aplicações e dos usos tradicionais e locais das plantas pelos humanos, de forma a permitir um melhor entendimento das maneiras pelas quais pessoas em comunidades distintas, observam, pensam, classificam, controlam, manipulam, manejam e utilizam espécies de plantas (ALBUQUERQUE, 2005; ALBUQUERQUE et al., 2007; ALBUQUERQUE e MEDEIROS, 2012). Portanto, a Etnobotânica passou a ser entendida como sendo um aparato bastante proveitoso no estudo das mudanças ambientais provocadas por fatores antropogênicos, como a diminuição da diversidade de ecossistemas, o desaparecimento de espécies de plantas, e a introdução de espécies exóticas ou alóctones em determinados ambientes, os quais causam distintos graus de degradação ambiental (KING e TEMPESTA, 1994; CUNNINGHAM, 2001; RODRÍGUEZSILVA et al., 2020).

No enfrentamento à essa pandemia, diversos povos têm recorrido ao conhecimento tradicional associado ao uso de plantas medicinais como estratégia local para o enfrentamento da nova doença. Dessa forma, as plantas medicinais tem contribuído como prática complementar na prevenção e no enfrentamento da Covid-19 e diversas estudos apontam para as suas potencialidades (ANG et al., 2020; BALKRISHNA et al., 2020; ETAWARE et al., 2020; GANGAL et al., 2020; LUO et al., 2020; THUY et al., 2020). 
Nesse sentido, essa pesquisa somou esforços para se unir aos demais trabalhos da área de Etnobiologia focados em uma perspectiva da "Etnobiologia da ação", ou "Etnobiologia socialmente situada", ou ainda, da "Etnobiologia engajada", em que são incentivadas pesquisas orientadas a partir das lutas dos sujeitos protagonistas dos nossos resultados. Assim, o retorno das pesquisas conduzidas junto aos povos precisa ser requalificado. As comunidades precisam ter acesso ao produto científico das pesquisas, como teses e artigos, de forma que os resultados encontrados cheguem de maneira adequada para cada contexto (TOMCHINSKY et al., 2019; SOLDATI e BARROS, 2020).

No Brasil, a tendência para estudos fortemente descritivos, baseados em listas de espécies é uma das característica dos estudos em Etnobotânica desde a década de 1980 (OLIVEIRA et al., 2009). De fato, estudos etnobotânicos tem potencial para servir como instrumento a fim de oportunizar o acesso a informações que podem ser úteis e valiosas para as comunidades pesquisadas (HANAZAKI, 2018).

Dessa maneira, apesar das plantas medicinais serem de vital importância ecológica, cultural e espiritual na tradição Kaiowá e Guarani, os estudos até agora realizados sobre o tema nas terras desses povos se cerceou à descrição de aspectos biológicos das plantas medicinais. Análises, comparações e reflexões sobre a temática arraigados na condição territorial desses povos foram pouco abordados na literatura atual. Portanto, neste artigo, apresentaremos as plantas medicinais usadas pelos povos Kaiowá e Guarani como prática complementar no enfrentamento dos sintomas da Covid-19, destacando a relevância do conhecimento etnobotânico desses povos como estratégia para lidar com situações adversas, como o caso atual de pandemia ocasionado pela Covid-19. No entanto, nesse estudo, consideramos como sintoma a ser observado e cuidado o sistema respiratório, já que esses vírus atacam, principalmente, esse sistema, causando a Síndrome Respiratória Aguda. Contudo, é importante pontuar que essa doença pode afetar o sistema gastrointestinal, coração, rim, fígado e sistema nervoso central, levando à múltipla falência de órgãos (LUI et al., 2020).

Desse modo, diante da delicada situação dos povos Kaiowá e Guarani frente à pandemia da Covid-19 e comprometidos com a vertente da Etnobiologia caracterizada como engajada ou socialmente situada, esperamos contribuir levantando (através de revisão bibliográfica) e discutindo, as plantas medicinais tradicionais Kaiowá e Guarani que podem ser usadas como prática complementar no enfrentamento dos sintomas da Covid-19. Dessa forma, discutimos a notoriedade do conhecimento tradicional como tática na luta pela sobrevivência, a favor da manutenção do modo de vida, baseada no bem viver, no bom relacionamento com a mata e com as plantas, o qual somente será possível a partir do processo de retomada de seus territórios e implantação de estratégias de restauração ecológica e conservação da biodiversidade.

\section{Aspectos metodológicos}

Neste trabalho, realizou-se um levantamento nas bases de dados Portal de Periódicos da Capes, Scientific Electronic Library (SciELO) e Google Acadêmico das produções científicas publicadas a partir de estudos realizados no Brasil até maio de 2020 sobre o tema 'plantas medicinais Kaiowá e Guarani', para o qual se utilizou a metodologia descritivo-analítico-reflexiva (MARCOLINO e MIZUKAMI, 2008). Adotouse, para nortear a revisão bibliográfica, o tema 'plantas medicinais usadas pelos povos Kaiowá e Guarani no cuidado do sistema respiratório'. A definição de estratégia de busca considerou as seguintes expressões em português, inglês e espanhol: 'Kaiowá' e 'Guarani', associadas aos grupos 'plantas medicinais', 'ervas medicinais', 'etnobotânica', 'plantas remédio'. Todos os trabalhos encontrados foram contemplados, incluindo artigos, capítulos de livros e dissertações.

Foi considerado um total de sete estudos (BUENO et al., 2005; REGO et al., 2010; BENITES E. et al., 2017; BENITES I. et al., 2017; LOPES et al., 2017; JOÃO et al., 2017; MILLION, 2017) realizados entre 2005 e 2017, nos municípios de Amambai (aldeia Amambai), Caarapó (aldeia Te'yikue), Dourados (aldeia Jaguapiru), Douradina (aldeia Panambi) e Juti (aldeia Taquara), todos do estado do Mato Grosso do Sul, forneceram as informações analisadas (Figura. 1). Dos sete estudos examinados, seis foram realizados em terras indígenas que já estão homologadas pela Justiça Federal e uma (aldeia Taquara em Juti) consta como terra ainda em processo de disputa judicial. Somente os estudos de texto completo nos 
quais o material botânico foi cuidadosamente identificado e documentado foram considerados nessa análise.

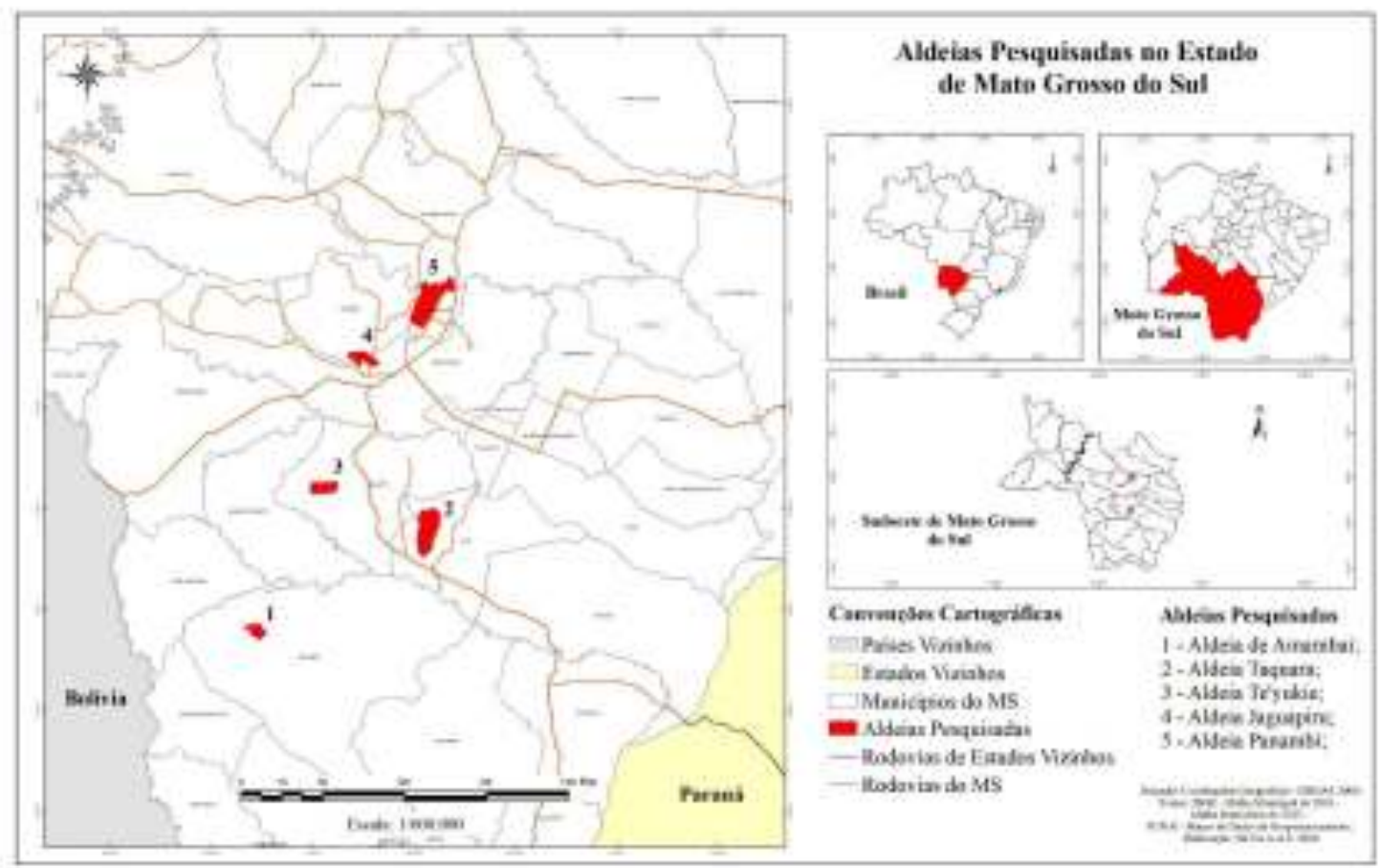

Figura 1. Mapa demonstrando a localização dos estudos etnobotânicos dos povos Kaiowá e Guarani examinados neste trabalho.

A partir dessas pesquisas analisadas, foram selecionadas somente as plantas cujos usos terapêuticos estavam relacionados ao sistema corporal respiratório, de acordo com a classificação da organização mundial da saúde (OMS, 2006). Assim, foram coletadas as seguintes informações: nomes científicos, nomes comuns, nomes êmicos (em guarani e/ou kaiowá) e parte utilizadas das plantas com recomendação terapêutica para o sistema respiratório. As espécies de plantas foram classificadas de acordo com o hábito de crescimento como: árvores, arbustos, subarbustos, liana ou herbáceo. Quando aos hábitos das plantas, não foram especificados no trabalho original, essas informações foram obtidas a partir de consulta ao banco de dados do projeto Flora do Brasil (2020) do Missouri Botanical Garden (МОВОT, 2020), consultados em maio de 2020; ou ainda, com a ajuda de especialistas da Universidade Federal da Grande Dourados (UFGD) e da Universidade Estadual de Mato Grosso do Sul (UEMS).

Todas as plantas com uso terapêutico direcionado para o sistema respiratório citadas nos sete estudos consultados estão listadas na Tabela 1. Tivemos o cuidado de empregar apenas os nomes científicos atuais, conforme listado nas bases de dados da Flora do Brasil 2020 e do Missouri Botanical Garden e, para identificar sinônimos, usamos a sinonímia entre colchetes na tabela e no texto. Na tabela, tivemos o cuidado de associar os dados com a respectiva citação, de forma que os números sobrescritos correspondem ao número sobrescrito da respectiva referência.

\section{Resultados e discussão}

Foi compilado um total de 31 espécies de angiospermas de uso terapêutico relacionado ao sistema respiratório, incluídas em 27 gêneros e 14 famílias (Tabela 1). De todas as catalogadas, 27 $(87,1 \%)$ são plantas nativas dos domínios fitogeográficos brasileiros, enquanto quatro $(12,9 \%)$ são espécies exóticas. 
Tabela 1. Lista de 31 espécies de plantas medicinais indicadas para o cuidado com o sistema respiratório pelos povos Kaiowá e Guarani, citadas em sete estudos da região Centro-oeste do Brasil: nome vernacular, domínio fitogeográfico, indicação terapêutica, parte usada, informações de uso, e as respectivas referências.

\begin{tabular}{|c|c|c|c|c|c|c|}
\hline $\begin{array}{c}\text { FAMÍLIA (Ordem) } \\
\text { Nome científico } \\
\text { autor }\end{array}$ & $\begin{array}{l}\text { Nome vernacular } \\
\text { (nome em } \\
\text { kaiowá e/ou } \\
\text { guarani) }\end{array}$ & $\begin{array}{c}\text { Domínio } \\
\text { Fitogeográfico } \\
\text { (hábito) }\end{array}$ & $\begin{array}{c}\text { Indicação } \\
\text { terapêutica } \\
\text { para o sistema } \\
\text { respiratório }\end{array}$ & $\begin{array}{l}\text { Parte } \\
\text { usada }\end{array}$ & $\begin{array}{l}\text { Informação de } \\
\text { uso }\end{array}$ & Referências \\
\hline \multicolumn{7}{|c|}{ AMARANTHACEAE (Caryophyllales) } \\
\hline $\begin{array}{c}\text { Alternanthera } \\
\text { brasiliana Kuntze }\end{array}$ & $\begin{array}{l}\text { terramicina } \\
\text { (arpirina) }\end{array}$ & $\begin{array}{c}\mathrm{A} / \mathrm{Ca} / \mathrm{Ce} / \mathrm{M} \\
\text { (subarbusto) }\end{array}$ & $\begin{array}{l}\text { febre, dor de } \\
\text { garganta }\end{array}$ & Fo & chá & $\begin{array}{c}\text { Benites I. et al., } \\
2017\end{array}$ \\
\hline $\begin{array}{c}\text { Achyrocline } \\
\text { satureioides (Lam.) } \\
\text { DC. }\end{array}$ & $\begin{array}{c}\text { macela } \\
\left(\text { macela }^{1}\right. \\
\left.\text { jateikaá }{ }^{2}\right)\end{array}$ & $\begin{array}{l}\mathrm{Ce} / \mathrm{M} / \mathrm{Pa} \\
\text { (herbáceo) }\end{array}$ & $\begin{array}{l}\text { febre }^{1} \text {, gripe }{ }^{1}, \\
\text { tosse } \\
\text { inflamação de } \\
\text { garganta }^{2}\end{array}$ & $\begin{array}{l}\mathrm{Fo}^{1,}, \\
\mathrm{~F}^{2}\end{array}$ & chá', 2 & $\begin{array}{l}\text { Benites I. et al., } \\
\quad 2017 \\
\text { 2João et al., } 2017\end{array}$ \\
\hline $\begin{array}{c}\text { Moquinia } \\
\text { racemosa (Spreng.) } \\
\text { DC. }{ }^{*}[\text { Gochnatia } \\
\text { barrosii Cabrera }]\end{array}$ & $\begin{array}{l}\text { borragem } \\
\text { do campo } \\
\qquad(-)\end{array}$ & $\begin{array}{c}\mathrm{Ce} / \mathrm{M} \\
\text { (arbusto) }\end{array}$ & $\begin{array}{l}\text { infecção } \\
\text { respiratória }\end{array}$ & $\begin{array}{l}\text { Fo } \\
\mathrm{S}\end{array}$ & chá & $\begin{array}{l}\text { Benites I. et al., } \\
2017\end{array}$ \\
\hline \multirow[t]{2}{*}{$\begin{array}{l}\text { Moquiniastrum } \\
\text { polymorphum } \\
\text { (Less.) G. Sancho } \\
\text { *[Gochnatia } \\
\text { polymorpha Herb. } \\
\text { Berol ex DC.] }\end{array}$} & $\begin{array}{l}\text { candeia', } \\
\text { cambará } \\
\text { (tatarêm }^{1}, \\
\text { ka'auvetîn }^{3} \text { ) }\end{array}$ & $\begin{array}{l}\mathrm{Ce} / \mathrm{M} \\
\text { (árvore) }\end{array}$ & $\begin{array}{c}\text { dor de } \\
\text { garganta }^{12}, \\
\text { tosse }^{2}, \text { gripe }^{2}, \\
\text { febre }^{2}, \\
\text { resfriado }^{3}\end{array}$ & $\begin{array}{l}\mathrm{C}^{1} \\
\mathrm{Fo}^{2,},\end{array}$ & chá & $\begin{array}{c}\text { 'Bueno et al., } 2005 \\
\text { 2Rego et al., } 2010 \\
{ }^{3} \text { Benites I. et al., } \\
2017\end{array}$ \\
\hline & \multicolumn{2}{|c|}{ BIGNONIACEAE (Lamiales) } & & & & \\
\hline $\begin{array}{l}\text { Fridericia florida } \\
\text { (DC.) L.G. Lohmann }\end{array}$ & $\begin{array}{l}\text { cipó-neve } \\
\text { (gwiri puña) }\end{array}$ & $\begin{array}{c}\mathrm{A} / \mathrm{M} / \mathrm{Ce} \\
\text { (liana) }\end{array}$ & pneumonia & $\mathrm{R}$ & $\begin{array}{c}\text { sem } \\
\text { informação }\end{array}$ & Million, 2017 \\
\hline $\begin{array}{l}\text { Handroanthus } \\
\text { impetiginosus } \\
\text { (Mart. ex DC.) *[ } \\
\text { Tabebuia } \\
\text { avellanedae } \\
\text { Lorentz ex Griseb.] }\end{array}$ & $\begin{array}{l}\text { ipê-roxo } \\
\text { (tajy) }\end{array}$ & $\begin{array}{c}\mathrm{M} / \mathrm{Ce} \\
\text { (árvore) }\end{array}$ & febre, gripe & C & chá & Bueno et al., 2005 \\
\hline $\begin{array}{c}\text { Ananas } \\
\text { ananassoides } \\
\text { (Baker) L.B.Sm. }\end{array}$ & $\begin{array}{c}\text { bromélia', } \\
\text { ananas-do-mato } \\
\text { (karaguata }^{2} \\
\text { pytã }{ }^{1} \\
\text { karaguatay }^{2} \text { ) }\end{array}$ & $\begin{array}{l}\mathrm{A} / \mathrm{Ca} / \mathrm{Ce} / \mathrm{M} \\
\text { (herbáceo) }\end{array}$ & $\begin{array}{l}\text { gripe }{ }^{1} \text {, dor de } \\
\text { garganta } 1, \\
\text { problemas } \\
\text { respiratórios }\end{array}$ & $\begin{array}{l}\mathrm{Fo}^{1} \\
\mathrm{Fr}^{1}, 2\end{array}$ & chá', 2 & $\begin{array}{c}\text { 'Million, } 2017 \\
\text { ²Benites I. et al., } \\
2017\end{array}$ \\
\hline \multirow[t]{2}{*}{$\begin{array}{c}\text { Bromelia } \\
\text { antiacantha } \\
\text { Bertol. }\end{array}$} & $\begin{array}{l}\text { caraguatá } \\
\text { (karaguata ju, } \\
\text { karaguata) }\end{array}$ & $\begin{array}{c}\mathrm{M} / \mathrm{Pa} \\
\text { (herbáceo) }\end{array}$ & Tosse & $\begin{array}{l}\mathrm{R} \\
\mathrm{Fr}\end{array}$ & xarope & $\begin{array}{c}\text { Benites I. et al., } \\
2017\end{array}$ \\
\hline & \multicolumn{2}{|c|}{ BURSERACEAE (Sapindales) } & & & & \\
\hline \multirow[t]{2}{*}{$\begin{array}{c}\text { Protium } \\
\text { heptaphyllum } \\
\text { (Aubl.) Marchand }\end{array}$} & $\begin{array}{c}\text { amescla }^{1}, \text { breu }^{2} \\
(y s y)\end{array}$ & $\begin{array}{c}\mathrm{A} / \mathrm{Ca} / \mathrm{Ce} / \mathrm{M} \\
\text { (arbusto) }\end{array}$ & gripe $^{1}, 2$ & $\mathrm{C}^{1}, 2 \mathrm{~Sv}^{2}$ & uso tópico ${ }^{1,2}$ & $\begin{array}{c}{ }^{1} \text { Rego et al., } 2010 \\
{ }^{2} \text { Benites E. et al., } \\
2017\end{array}$ \\
\hline & \multicolumn{2}{|c|}{ CELASTRACEAE (Celastrales) } & & & & \\
\hline
\end{tabular}




\begin{tabular}{|c|c|c|c|c|c|c|}
\hline $\begin{array}{l}\text { Hippocratea } \\
\text { volubilis L. }\end{array}$ & $\begin{array}{c}\text { cipó-preto } \\
\text { (ka hogue ne) }\end{array}$ & $\begin{array}{c}\mathrm{A} / \mathrm{Ca} / \mathrm{Ce} / \mathrm{M} / \mathrm{Pt} \\
\text { (liana) }\end{array}$ & Gripe & Fo & $\begin{array}{c}\text { sem } \\
\text { informação }\end{array}$ & Million, 2017 \\
\hline \multicolumn{7}{|c|}{ EUPHORBIACEAE (Malpighiales) } \\
\hline $\begin{array}{l}\text { Croton } \\
\text { floribundus } \\
\text { Spreng. }\end{array}$ & $\begin{array}{l}\text { capixingui }{ }^{1} \\
\text { (yvyravevýi }^{1}, \\
\left.\text { tatarẽ }^{2}\right)\end{array}$ & $\begin{array}{l}\mathrm{Ca} / \mathrm{Ce} / \mathrm{M} \\
\text { (árvore) }\end{array}$ & $\begin{array}{c}\text { dor de } \\
\text { garganta }{ }^{12}\end{array}$ & $\begin{array}{l}\mathrm{C}^{1} \\
\mathrm{R}^{1}, 2\end{array}$ & chá $^{1}, 2$ & $\begin{array}{l}{ }^{1} \text { Rego et al., } 2010 \\
\text { 2Million, } 2017\end{array}$ \\
\hline $\begin{array}{c}\text { Croton urucurana } \\
\text { Bail }\end{array}$ & $\begin{array}{l}\text { sangra d'água1, } \\
\text { árvore } \\
\text { vermelha }{ }^{2} \\
\text { (urucurã }^{1}, \text { yviro } \\
\left.\text { pyto }{ }^{2}\right)\end{array}$ & $\begin{array}{l}\text { A/Ce/M } \\
\text { (árvore) }\end{array}$ & $\begin{array}{l}\text { inflamação de } \\
\text { garganta }^{12}\end{array}$ & $\begin{array}{l}\mathrm{C}^{1} \\
\mathrm{~Sv}^{2}\end{array}$ & chá $^{1}, 2$ & $\begin{array}{c}\text { 1João et al., } 2017 \\
\text { 2Lopes et al., } \\
2017\end{array}$ \\
\hline \multicolumn{7}{|c|}{ FABACEAE (Fabales) } \\
\hline $\begin{array}{c}\text { Copaifera } \\
\text { langsdorffii Desf. }\end{array}$ & $\begin{array}{l}\text { pau-de-óleo } \\
\text { (kupa'y) }\end{array}$ & $\begin{array}{l}\mathrm{Ca} / \mathrm{Ce} / \mathrm{M} \\
\text { (árvore) }\end{array}$ & Gripe & $\mathrm{C}$ & chá & $\begin{array}{l}\text { Bueno et al., } \\
2005\end{array}$ \\
\hline $\begin{array}{l}\text { Lonchocarpus } \\
\text { sericeus (Poir.) } \\
\text { Kunth ex DC. }\end{array}$ & 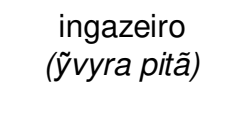 & $\begin{array}{l}\text { A/Ca/Ce/M } \\
\text { (árvore) }\end{array}$ & $\begin{array}{l}\text { dor de } \\
\text { garganta }\end{array}$ & $\mathrm{C}$ & $\begin{array}{c}\text { sem } \\
\text { informação }\end{array}$ & Million, 2017 \\
\hline $\begin{array}{c}\text { Machaerium } \\
\text { acutifolium Vogel }\end{array}$ & $\begin{array}{l}\text { limão-do- } \\
\text { campo } \\
\text { (ysapy'y, } \\
\text { yvyraitamirĩ) }\end{array}$ & $\begin{array}{l}\mathrm{A} / \mathrm{Ca} / \mathrm{Ce} / \mathrm{M} \\
\text { (árvore) }\end{array}$ & $\begin{array}{c}\text { inflamação na } \\
\text { garganta }\end{array}$ & $\mathrm{C}$ & chá & João et al., 2017 \\
\hline $\begin{array}{c}\text { Peltophorum } \\
\text { dubium (Spreng.) } \\
\text { Taub. }\end{array}$ & $\begin{array}{l}\text { canafístula } \\
\text { (yvira pitã) }\end{array}$ & $\begin{array}{l}\mathrm{Ca} / \mathrm{Ce} / \mathrm{M} / \mathrm{Pt} \\
\text { (árvore) }\end{array}$ & gripe & Fo & $\begin{array}{c}\text { sem } \\
\text { informação }\end{array}$ & Rego et al., 2010 \\
\hline $\begin{array}{c}\text { Pterodon } \\
\text { emarginatus Vog. } \\
{ }^{*}[\text { Sucetia } \\
\text { fruticosa }]^{2}\end{array}$ & $\begin{array}{l}\text { sucupira } \\
\text { (yviraperó) }\end{array}$ & $\begin{array}{l}\mathrm{A} / \mathrm{Ca} / \mathrm{Ce} / \mathrm{Pt} \\
\text { (árvore) }\end{array}$ & $\begin{array}{l}\text { febre }^{1}, \text { gripe }^{2} \\
\text { tosse }^{2}\end{array}$ & $\begin{array}{l}\mathrm{C}^{2} \\
\mathrm{~S}^{1}, 2\end{array}$ & chá $^{1}, 2$ & $\begin{array}{l}\text { 'Bueno et al., } \\
2005 \\
\text { 'Benites et al., } \\
2017\end{array}$ \\
\hline \multicolumn{7}{|c|}{ LAMIACEAE (Lamiales) } \\
\hline Hyptis Jacq. sp. & $\begin{array}{l}\text { cânfora-do- } \\
\text { cerrado } \\
\text { (akãfor) }\end{array}$ & $\begin{array}{c}\mathrm{Ce} \\
\text { (herbáceo) }\end{array}$ & $\begin{array}{l}\text { doenças } \\
\text { respiratórias }\end{array}$ & Fo & chá & $\begin{array}{l}\text { Benites l. et al., } \\
2017\end{array}$ \\
\hline \multicolumn{7}{|c|}{ LOGANIACEAE (Gentianales) } \\
\hline $\begin{array}{l}\text { Strychnos bicolor } \\
\text { Progel }\end{array}$ & $\begin{array}{l}\text { quina } \\
\text { (xirika'i) }\end{array}$ & $\begin{array}{c}\mathrm{Ce} / \mathrm{M} \\
\text { (liana) }\end{array}$ & Gripe & $\begin{array}{l}\text { R } \\
\text { Fo }\end{array}$ & chá & Million, 2017 \\
\hline \multicolumn{7}{|c|}{ LYTHRACEAE (Myrtales) } \\
\hline $\begin{array}{l}\text { Lafoensia pacari } \\
\text { A. St.-Hil }\end{array}$ & $\begin{array}{l}\text { pacuri } \\
(-)\end{array}$ & $\begin{array}{c}\mathrm{Ce} \\
\text { (árvore) }\end{array}$ & pneumonia & $\mathrm{Fr}$ & chá & $\begin{array}{l}\text { Bueno et al., } \\
2005\end{array}$ \\
\hline \multicolumn{7}{|c|}{ MALPIGHIACEAE (Malpighiales) } \\
\hline $\begin{array}{c}\text { Guazuma } \\
\text { ulmifolia Lam. }\end{array}$ & $\begin{array}{c}\text { mutambo } \\
\text { (gua'a resay) }\end{array}$ & $\begin{array}{l}\mathrm{A} / \mathrm{Ca} / \mathrm{Ce} / \mathrm{M} \\
\text { (árvore) }\end{array}$ & $\begin{array}{l}\text { inflamação de } \\
\text { garganta }\end{array}$ & $\mathrm{C}$ & chá & $\begin{array}{l}\text { Benites E. et al., } \\
\qquad 2017\end{array}$ \\
\hline $\begin{array}{l}\text { Cedrela fissilis } \\
\text { Vell. }\end{array}$ & $\begin{array}{c}\text { cedro } \\
\text { (yary } 1 / \\
\text { yuyrakatingy }{ }^{2}, \\
\left.\text { seyro }{ }^{3}\right)\end{array}$ & $\begin{array}{l}\text { A/Ce/M } \\
\text { (árvore) }\end{array}$ & $\begin{array}{l}\text { gripe }{ }^{12}, \text { dor de } \\
\text { garganta }^{2} \\
\text { febre }^{23}\end{array}$ & $\mathrm{C}^{1},{ }^{2,3}$ & chá ${ }^{1},{ }^{2}, 3$ & $\begin{array}{c}\text { 1Bueno et al., } \\
2005 \\
\text { 2Million, } 2017 \\
\text { 3Benites E. et al., } \\
2017\end{array}$ \\
\hline
\end{tabular}




\begin{tabular}{|c|c|c|c|c|c|c|}
\hline $\begin{array}{l}\text { Eucalyptus } \\
\text { L'Hér. sp. }\end{array}$ & $\begin{array}{c}\text { eucalipto } \\
\text { (kalipio) }\end{array}$ & $\begin{array}{l}\text { Cultivada } \\
\text { (árvore) }\end{array}$ & $\begin{array}{l}\text { febre, gripe, } \\
\text { tosse }\end{array}$ & Fo & Chá & $\begin{array}{c}\text { Benites I. et al., } \\
2017\end{array}$ \\
\hline \multirow{2}{*}{$\begin{array}{c}\text { Piper umbellatum } \\
\text { L. *[Pothomorphe } \\
\text { umbellata Miq.] }\end{array}$} & $\begin{array}{c}\text { pariparoba } \\
\text { (parioparova) }\end{array}$ & $\begin{array}{c}\mathrm{A} / \mathrm{Ce} / \mathrm{M} \\
\text { (subarbusto) }\end{array}$ & gripe, febre & Fo & Chá & $\begin{array}{l}\text { Bueno et al., } \\
2005\end{array}$ \\
\hline & \multicolumn{2}{|c|}{ POACEAE (Poales) } & & & & \\
\hline \multirow[t]{2}{*}{$\begin{array}{l}\text { Cymbopogon } \\
\text { citratus (DC.) } \\
\text { Stapf. }\end{array}$} & $\begin{array}{l}\text { capim cidreira } \\
\text { (ka'a kapi'i, } \\
\text { kapi'isedron) }\end{array}$ & $\begin{array}{l}\text { Cultivada } \\
\text { (herbáceo) }\end{array}$ & $\begin{array}{l}\text { gripe, tosse, } \\
\text { febre, } \\
\text { resfriado }\end{array}$ & $\begin{array}{l}\text { Fo } \\
\text { R }\end{array}$ & chá & $\begin{array}{l}\text { Benites I. et al., } \\
2017\end{array}$ \\
\hline & \multicolumn{2}{|c|}{ RUTACEAE (Sapindales) } & & & & \\
\hline $\begin{array}{c}\text { Citrus aurantium } \\
\text { L. }\end{array}$ & $\begin{array}{l}\text { Iaranja azeda } \\
\text { (naranhã hai) }\end{array}$ & $\begin{array}{l}\text { Cultivada } \\
\text { (árvore) }\end{array}$ & Gripe & $\mathrm{Fr}$ & chá & $\begin{array}{c}\text { Benites I. et al., } \\
2017\end{array}$ \\
\hline $\begin{array}{c}\text { Citrus limon (L.) } \\
\text { Osbeck }\end{array}$ & $\begin{array}{l}\operatorname{limão}_{(-)}^{(-)} \\
\text {SOLANACEA }\end{array}$ & $\begin{array}{c}\text { Cultivada } \\
\text { (árvore) } \\
\text { E (Solanales) }\end{array}$ & gripe, tosse & $\begin{array}{l}\text { Fo } \\
\text { Fr }\end{array}$ & chá & $\begin{array}{c}\text { Benites l. et al., } \\
2017\end{array}$ \\
\hline $\begin{array}{c}\text { Solanum } \\
\text { bonariense L. }\end{array}$ & $\begin{array}{c}\text { jurubeba brava } \\
(-)\end{array}$ & $\begin{array}{c}\mathrm{M} \\
\text { (arbusto) }\end{array}$ & $\begin{array}{c}\text { dor de } \\
\text { garganta }\end{array}$ & Fo & chá & $\begin{array}{c}\text { Benites l. et al., } \\
2017\end{array}$ \\
\hline $\begin{array}{c}\text { Solanum } \\
\text { palinacanthum } \\
\text { Dunal }\end{array}$ & $\begin{array}{c}\text { jurubeba } \\
\text { (ãyrañapaw) }\end{array}$ & $\begin{array}{c}\mathrm{A} / \mathrm{Ca} / \mathrm{Ce} / \mathrm{M} / \mathrm{Pa} / \mathrm{Pt} \\
\text { (arbusto) }\end{array}$ & Gripe & $\begin{array}{l}\text { Fr } \\
\text { Fo }\end{array}$ & chá & $\begin{array}{c}\text { Benites I. et al., } \\
2017\end{array}$ \\
\hline \multirow[t]{2}{*}{$\begin{array}{c}\text { Solanum } \\
\text { subinerme Jacq. }\end{array}$} & $\begin{array}{c}\text { juúna } \\
\text { (yvyra vevui) }\end{array}$ & $\begin{array}{c}\mathrm{A} / \mathrm{Ce} \\
\text { (arbusto) }\end{array}$ & $\begin{array}{l}\text { inflamação } \\
\text { de garganta }\end{array}$ & C & chá & Million, 2017 \\
\hline & \multicolumn{2}{|c|}{ URTICACEAE (Rosales) } & & & & \\
\hline $\begin{array}{c}\text { Cecropia } \\
\text { pachystachya } \\
\text { Trécul }\end{array}$ & $\begin{array}{c}\text { embaúba, lixa } \\
\text { de macaco } \\
\text { (ka'i pokova }^{1} \text {, } \\
\text { amba'y } \\
\left.\text { ru'ãgue }^{2}\right) \\
\end{array}$ & $\begin{array}{c}\mathrm{A} / \mathrm{Ca} / \mathrm{Ce} / \mathrm{M} / \mathrm{Pt} \\
\text { (árvore) }\end{array}$ & $\begin{array}{c}\text { dor de } \\
\text { garganta }\end{array}$ & $\begin{array}{l}\mathrm{C}^{1} \\
\mathrm{Fo}^{1}, 2\end{array}$ & chá & $\begin{array}{c}\text { 'Million, } 2017 \\
\text { Benites l. et al., } \\
2017\end{array}$ \\
\hline
\end{tabular}

A (Amazônia); Ca (Caatinga); Ce (Cerrado); M (Mata Atlântica); Pa (Pampa), Pt (Pantanal)

C (casca); Fo (folha); Fr (fruto); R (raiz); S (semente); Sv (seiva)

Os nomes científicos em colchetes se referem às espécies com nomes científicos conforme citados nas fontes consultadas originais, atualizados aqui. Os números sobrescritos correspondem ao número sobrescrito da respectiva referência.

O número de plantas medicinais de uso terapêutico relacionado ao sistema respiratório citadas nas publicações variou de um (LOPES et al., 2017) a quinze (BENITES I. et al., 2017). Fabaceae se destacou como sendo a família mais rica (cinco spp.), seguida pelas famílias Amaranthaceae, Bignoniaceae e Malpighiaceae (quatro espécies cada). Nenhuma espécie compilada da literatura faz parte da Relação Nacional de Plantas Medicinais de Interesse ao SUS (RENISUS).

Nesse sentido, é importante ressaltar que essas quatro famílias, cuja riqueza florística merece destaque, são bastante comuns na Mata Atlântica (HANAZAKI et al., 2000; DI STASI et al., 2002; GAZZANEO et al., 2005), bioma predominante no território Kaiowá e Guarani (COLMAN e PEREIRA, 2020). Essas famílias também são encontradas entre os grupos mais representativos em estudos etnobotânicos brasileiros de outros biomas, como o Cerrado (AMOROZO, 2002) e a Floresta Amazônica (RODRIGUES, 2006).

As espécies que foram mais citadas entre os sete trabalhos analisados foram Cedrela fissilis (Fabaceae) e Moquiniastrum polymorphum (Amaranthaceae) (três trabalhos cada), seguidas por espécies Achyrocline satureioides (Amaranthaceae); Ananas ananassoides (Bignoneaceae); Protium heptaphyllum (Burseraceae); Croton floribundus, Croton urucurana (Euphorbiaceae); Pterodon emarginatus (Fabaceae); e Cecropia pachystachya (Urticaceae) (dois trabalhos cada). As demais espécies foram citadas individualmente em cada um dos trabalhos analisados. 
C. fissilis (cedro) é distribuída em todo o Brasil, sendo mais frequente nas regiões sul e sudeste do país. Por exibir alto valor comercial e econômico, é alvo do extrativismo e da exploração, o que justifica sua inclusão na lista de espécies em risco de extinção. Essa espécie, historicamente, vem sofrendo com a exploração madeireira ao longo de toda a sua ocorrência, o que levou muitas das subpopulações à extinção (MARTINS e LAGO, 2008). Além disso, grande parte dos seus habitats foram completamente destruídos, tendo sido convertidos em áreas urbanas, pastagens e plantações, como no caso do estado do Mato Grosso do Sul (PAULILO et al., 2008).

Cortez et al. (2008) e Carminati et al (2014) comprovaram atividade antibacteriana de extratos do caule e folhas de $C$. fissilis. Não encontramos registro de toxicidade dessa espécie indicada na literatura. Em relação às informações de uso das plantas medicinais encontradas nos trabalhos etnobotânicos Kaiowá e Guarani, encontramos, majoritariamente, a indicação na forma de infusão (chá).

Já M. polymorphum, conhecida popularmente como cambará-de-folha-grande e cambará-domato se distribui pelas regiões Centro-oeste, Nordeste e Sudeste (SANCHO, 2000). Essa espécie já é reconhecida na medicina popular no tratamento de doenças brônquio-pulmonares (MORS et al., 2000). Em relação à toxidade dessa espécie, estudos apontam toxicidade para gestantes, além de alteração no desempenho reprodutivo, fatos que contraindicam a utilização em período gestacional (PESSATO et al., 2015). Assim, o uso deve seguir as orientações tradicionais.

É importante ressaltar que as principais espécies de plantas encontradas neste trabalho são comumente citadas como tendo grande importância cultural como plantas medicinais na região Centrooeste do Brasil (PEREIRA et al., 2009, 2012; CARNEIRO e SANTOS, 2013, 2014; BRATTI, et al., 2013; FONSECA et al., 2015).

Em relação ao hábito de crescimento, encontramos que a maioria das plantas medicinais usadas pelos Kaiowá e Guarani no cuidado do sistema respiratório foram as plantas de hábito arbóreo ( $\mathrm{n}=16$, $51,6 \%)$, seguida pelos hábitos arbustivo e herbáceo $(n=5 ; 16,1 \%$ cada), de liana $(n=3 ; 9,6 \%)$ e subarbustivo ( $n=2 ; 6,4 \%$ ). De fato, os Kaiowá e Guarani mantém uma relação muito intrínseca com a Mata Atlântica, caracterizada por pela presença de espécies de árvores de médio e grande porte que formam uma floresta densa e fechada (COLMAN e PEREIRA, 2020).

A cobertura da vegetação originária do território Kaiowá e Guarani se constituía como um mosaico de confluência entre áreas de floresta, campos e cerrado, o que produzia a inter-relação de paisagens. Estabelecia-se o manejo de cultivos em formações florestais classificadas como Mata Atlântica e nas áreas de Campos e Cerrado estabeleciam-se as práticas da caça e coleta (PEREIRA, 2016).

Em todo o estado, o desmatamento da floresta ocorreu de forma violenta e intensa, já durante o século XX, processo que os Kaiowá e Guarani relacionam à ampliação da desarticulação da organização sócio-territorial das coletividades, para a implementação das fazendas. Portanto, é fundamental compreender que a recuperação dos territórios é de vital importância para a manutenção da saúde em sua compreensão holística das coletivas indígenas analisadas. Dessa forma, as novas territorialidades e organização política Kaiowá e Guarani têm sido indissociável de estratégias vinculadas à processos de recuperação da mata e da reaproximação dos guardiões da mata que trazem consigo outros animais, pássaros, plantas e seres diversos (PEREIRA, 2014).

Em relação aos domínios fitogeográfico e considerando apenas as plantas nativas, encontramos que a maioria das plantas citadas $(n=21 ; 85,2 \%)$ são plantas de ocorrência na Mata Atlântica. A Mata Atlântica no Mato Grosso do Sul inclui formações florestais (primárias e secundárias em estágio avançado de regeneração) de floresta estacional decidual e floresta estacional semidecidual, matas ciliares, remanescentes incrustados ou inseridos em outras formações a exemplo do Cerrado e do Pantanal. Fragmentos isolados no interior das diversas áreas indígenas situadas no sudoeste do Estado estão entre os principais remanescentes desse Bioma na região sul do estado, confirmando a importância dos povos indígenas na conservação e restauração ambiental (MELLO et al., 2011). 
A pandemia atual causada pelo novo coronavírus (SARS-CoV-2), causador da doença Covid-19, emanou da natureza e mostrou como a saúde humana está intimamente interligada com a relação humana e o meio ambiente. À medida que invadimos os ambientes naturais e esgotamos habitats vitais, um número crescente de espécies se coloca em risco, incluindo a espécie Homo sapiens. Nesse sentido, é possível refletir a possibilidade de que pandemias possam estar relacionadas a uma plausível reação da Terra, tão adoentada diante das brutais agressões centralizadas pelas mentes e mãos humanas, cuja falta de saberes e de humanidade transformou a natureza em produto e mercadoria.

Assim, o mundo pandêmico expôs completamente a fragilidade do nosso Estado e a perversão do sistema capitalista em sua versão neoliberal. A propagação da pandemia em todo o planeta torna todos vulneráveis em qualquer canto do mundo, o que não deve ser confundido com o não reconhecimento da alta vulnerabilidade dos povos indígenas devido à situação de ataques e exclusão histórica. Essas populações interligadas de maneira especial e holística ao meio natural podem ensinar ao mundo não indígena conhecimentos e saberes úteis no enfrentamento das múltiplas crises do futuro imediato, seja ele sanitário, ambiental, climático ou pandêmico.

Do ponto de vista etnobiológico, e considerando as limitações deste estudo, entendemos que as plantas medicinais de um determinado povo podem ser apontadas como critério importante na seleção de espécies de plantas para estudos mais detalhados sobre diversos aspectos, como ecológicos e referentes à conservação e restauração da biodiversidade local; assim como antropológicos, a respeito das relações e ações políticas e espaciais de povos com seu território.

Nossa análise demonstrou que há um número expressivo de espécies de plantas medicinais usadas no trato e cuidado do sistema respiratório, conhecidas nas culturas Kaiowá e Guarani e que, possivelmente, podem ser usadas como ferramentas para o enfrentamento de sintomas gripais associado à Covid-19.

Por outro lado, nossas reflexões também apontam para a necessidade de um exame detalhado dos processos políticos sociais que vêm ocorrendo de forma intensa e que têm tido como resultado a dizimação do restante da biodiversidade dos territórios indígenas de todo o país e, em especial, do território Kaiowá e Guarani. Isso faz com que as estratégias locais, como a valorização do conhecimento tradicional, sejam prejudicadas, já que se o território tradicional deixa de existir, desaparece, também, todo o conhecimento tradicional, já que este conhecimento é fortemente associado à fauna e à flora local.

Dessa forma, este estudo demonstrou a importância Etnobotânica e Etnoecologia de pesquisas baseadas em fontes secundárias, ou seja, a partir de um conhecimento já estabelecido, com o intuito de trazer novas análises e reflexões. Um fato que consideramos relevante é que a grande maioria das plantas examinadas aqui são plantas nativas do território Kaiowá e Guarani e que possuem grande importância biológica e cultural para esses povos, dessa forma, sugerimos que essas espécies sejam consideradas como prioritárias em estratégias de preservação, conservação e/ou restauração ambiental.

As análises aqui apresentadas foram baseadas em uma série de estudos realizados usando distintas metodologias e cobrindo uma pequena área geográfica. Territórios Kaiowá e Guarani mais ao sudoeste do estado ainda não foram amostrados, por isso, sugerimos que nessa região trabalhos etnobotânicos sejam desenvolvidos, já que o domínio fitogeográfico e possivelmente as espécies vegetais dessa área sejam distintos dos das áreas até aqui amostradas.

A busca pela construção de conhecimentos pautados a partir de saberes tradicionais e locais se mostra como sendo de grande relevância, principalmente em épocas de crise, como a ocasionada pela pandemia da Covid-19, em que todas as informações científicas são fatores chave nas estratégias de enfrentamento dessa doença. Estudos científicos que abordam esses saberes têm sido conduzidos em diversas partes do mundo, indicando que as plantas medicinais são uma importante alternativa aos remédios sintéticos e que muitos remédios foram desenvolvidos a partir de fontes naturais, provenientes de conhecimento tradicional e/ou local, Esses conhecimentos precisam ser considerados e 
valorizados, já que partem de uma compreensão holística e dinâmica do conceito 'saúde' (SILVA et al., 2020; UZAR e UZAR, 2020)

Por fim, sublinhamos que, neste trabalho, nos aspectos que se referem à construção, execução, apresentação dos resultados e retorno às comunidades, nos somamos aos estudos pensados e construídos no âmbito da Etnobiologia socialmente engajada ou Etnobiologia da política e da ação, em que se busca reconhecer, refletir e interagir diante dos processos históricos, políticos e sociais, nos quais os povos, que são os principais atores na construção dessa ciência, estão inseridos. Almejamos, assim, construir uma Etnobiologia focada no reconhecimento e apoio às lutas dos povos na retomada de seus territórios ancestrais.

Assim, finalizamos este trabalho com as palavras do Xamã Davi Kopenawa Yanomami:

As coisas que os brancos extraem das profundezas da terra com tanta avidez, os minérios e o petróleo, não são alimentos. São coisas maléficas e perigosas, impregnadas de tosses e febres, que só Omama conhecia. Ele, porém, decidiu, no começo, escondê-las sob o chão da floresta para que não nos deixassem doentes [...]. São essas as palavras dos nossos espíritos, que os brancos desconhecem. Eles já possuem mercadorias mais do que suficientes. Apesar disso, continuam cavando o solo sem trégua, como tatus-canastra. Não acham que, fazendo isso, serão tão contaminados quanto nós somos. Estão enganados [...] (KOPENAWA, 2015, p. 357).

\section{Referências}

ALBUQUERQUE, U. P. Introdução à Etnobotânica. Rio de Janeiro: Interciência, 2005. 80p.

ALBUQUERQUE, U. P.; et al. Medicinal plants of the caatinga (semi-arid) vegetation of NE Brazil: a quantitative approach. Journal of ethnopharmacology, v. 114, n. 3, p.325-354, 2007.

ALBUQUERQUE, U. P.; MEDEIROS, P. M. Systematic reviews and meta-analysis applied to ethnobiological research. Ethnobiology and Conservation, v. 1, p.1-11, 2012.

AMOROZO, M. C. M. Uso e diversidade de plantas medicinais em Santo Antônio do Leverger, MT, Brasil. Acta Botanica Brasílica, v. 16, n. 2, p.189-203, 2002.

ANG, L.; et al. Herbal medicine and pattern identification for treating COVID-19: a rapid review of guidelines. Integrative Medicine Research, v. 9, n. 2, p.1-14, 2020.

BALKRISHNA, A.; et al. Super Critical Fluid Extracted Fatty Acids from Withania somnifera Seeds Repair PsoriasisLike Skin Lesions and Attenuate Pro-Inflammatory Cytokines (TNF- $\alpha$ and IL-6) Release. Biomolecules, v. 10, p.185, 2020.

BENITES, E. Oguata Pyahu (Uma Nova Caminhada) no processo de desconstrução e construção da educação escolar indígena da aldeia Te'ýikue. Dissertação (Mestrado em Educação) - Universidade Católica Dom Bosco, Campo Grande, 2014.

BENITES, E.; et al. O estudo das espécies arbóreas e o significado das mesmas para a cosmologia Guarani e Kaiowa da aldeia Te'yikue município de Caarapó-MS. In: SANGALLI, A.; LADEIA, E. S; BENITES, E.; PEREIRA, V. Z. (Orgs.). Tekoha Ka'aguy: Diálogos entre saberes Guarani e Kaiowá e o ensino de Ciências da Natureza. Jundiaí: Paco Editorial, 2017, v. 1, p. 83-106.

BENITES, I. L.; et al. As plantas medicinais e o ensino da botânica na aldeia Amambai. In: SANGALLI, A.; LADEIA, E. S; BENITES, E.; PEREIRA, V. Z. (Orgs.). Tekoha Ka'aguy: Diálogos entre saberes Guarani e Kaiowá e o ensino de Ciências da Natureza. Jundiaí: Paco Editorial, 2017, v. 1, p. 55-81.

BENITES, E. Tekoha Ñeropu'ã: aldeia que se levanta. Revista Nera, Dossiê, v. 23, n. 52, p.19-38, 2020.

BRAND, A. Desenvolvimento Local em comunidades indígenas no Mato Grosso do Sul: a construção de alternativas. Interações, Revista Internacional de Desenvolvimento Local, vol. 1, n. 2, p.59-68, 2001.

BRAND, A. J. Biodiversidade, sócio-diversidade e desenvolvimento: os Kaiowá e Guarani no Estado de Mato Grosso do Sul. In: COSTA, R. B. (Org.). Fragmentação florestal e alternativas de desenvolvimento rural na região Centro-Oeste. Campo Grande: UCDB, 2003, p. 175-204.

BRATTI, C.; et al. Levantamento de plantas medicinais nativas da Fazenda Azulão em Dourados-MS. Revista Brasileira de Plantas Medicinais, v. 15, n. 4, p.675-683, 2013.

BUENO, N. R.; et al. Medicinal plants used by the Kaiowá and Guarani indigenous populations in the Caarapó Reserve, Mato Grosso do Sul, Brazil. Acta Botanica Brasilica, v. 19, n. 1, p.39-44, 2005. 
ALMEIDA, S. C.; NÖTZOLD, A. L. V. O impacto da colonização e imigração no Brasil meridional: contágios, doenças e ecologia humana dos povos indígenas. Tempos Acadêmicos, n. 6, p.1-18, 2010.

CARMINATE, B.; et al. Investigação antibacteriana in vitro de extratos etanólicos das folhas e cascas de Cedrela fissilis Vell. Ciência e Natura, v.36, p.335-340, 2014.

CARNEIRO, M. R. B.; SANTOS, M. L. Os recursos vegetais medicinais utilizados pela população da região Centro Oeste do Brasil: uma compilação de espécies ou Checklist de Fanerógamas. Fronteiras: Journal of Social, Technological and Environmental Science, v. 2, n. 1, p.28-42, 2013.

CARNEIRO, M. R. B.; SANTOS, M. L. Importância relativa de espécies com potencial uso medicinal na flora do Centro Oeste do Brasil. Fronteiras: Journal of Social, Technological and Environmental Science, v. 3, n. 2, p.145163, 2014.

CISCATI, R. Isolados pela Covid-19, indígenas temem passar fome no MS. Disponível em: < https://www.brasildedireitos.org.br/noticias/571-isolados-pela-covid-19-indge >. Acesso em: 02 jun. 2020.

COLMAN, R. S. Território e sustentabilidade: os Guarani e o Kaiowá de Yvy Katu. 2007. Dissertação (Mestrado em Desenvolvimento Local) - Universidade Católica Dom Bosco, Campo Grande, 2007.

CONSELHO INDIGENISTA MISSIONÁRIO. Nota do Cimi Regional Mato Grosso do Sul sobre a pandemia de covid-19 entre os Kaiowá e Guarani. Disponível em: < https://cimi.org.br/2020/05/nota-do-cimi-ms-sobre-pandemiacovid-19-entre-kaiowa-guarani/ >. Acesso em: 02 jun. 2020.

CORTEZ, D. A. G.; et al. Atividade antibacteriana de extratos do caule de Cedrela fissilis Vell.(Meliaceae). Acta Scientiarum. Health Sciences, v. 20, p.243-245, 1998.

CHUA, K. B.; et al. Anthropogenic deforestation, El Nino and the emergence of Nipah virus in Malaysia. Malaysian Journal of Pathology, v. 24, n. 1, p.15-21, 2002.

COLMAN, R. S.; PEREIRA, L. M. Territorialidade e Sustentabilidade: Desafios para as comunidades Kaiowá e Guarani em Mato Grosso do Sul, Brasil. Revista Nera, n. 52, p. 63-89, 2020.

CUCINOTTA, D.; VANELLI, M. WHO declares COVID-19 a pandemic. Acta biomédica: Atenei Parmensis, v. 91, n. 1, p.157-160, 2020.

CUNNINGHAM, A. Etnobotánica aplicada. Pueblos, uso de plantas silvestres y conservación. Montevideo: Ed. Nordan-Comunidad, 2001. 310p.

DI STASI, L. C.; et al. Medicinal plants popularly used in the Brazilian Tropical Atlantic Forest. Fitoterapia, v. 73, p.69-91, 2002.

DUARTE, E. A.; et al. RNA virus quasispecies: significance for viral disease and epidemiology. Infectious agents and disease, v. 3, n. 4, p.201-214, 1994.

ELLWANGER, J. H.; et al. Beyond diversity loss and climate change: Impacts of Amazon deforestation on infectious diseases and public health. Anais da Academia Brasileira de Ciências, v. 92, n. 1, p. 1-33, 2020.

EREMITES de OLIVEIRA, J. Cultura material e identidade étnica na arqueologia brasileira: um estudo por ocasião da discussão sobre a tradicionalidade da ocupação Kaiowá da terra indígena Sucuri y. Sociedade e Cultura, v. 10, n. 1, p. 95-113, 2007.

ETAWARE, P. M. Medicinal plants, synthetic drugs or clinical therapy: The safest option against the pandemic Covid-19 Coronavirus. Pharmacology and Alternative Medicine Academic Journal. vol.5, n.3, p. 1-15, 2020.

FLORA DO BRASIL. Jardim Botânico do Rio de Janeiro. Disponível em: < http://floradobrasil.jbrj.gov.br/reflora/listaBrasil/ConsultaPublicaUC/ConsultaPublicaUC.do\#CondicaoTaxonCP > Acesso em: 28 ago. 2020.

FONSECA, M. C. M.; et al. Potencial de óleos essenciais de plantas medicinais no controle de fitopatógenos. Revista Brasileira de Plantas Medicinais, v. 17, n. 1, p.45-50, 2015.

GANGAL, N.; et al. Reconsidering Traditional Medicinal Plants to Combat COVID-19. AlJR Preprints. v. 1, p. 1-6, 2020.

GAZZANEO, L. R. S.; et al. Knowledge and use of medicinal plants by local specialists in an region of Atlantic Forest in the state of Pernambuco (Northeastern Brazil). Journal of Ethnobiology and Ethnomedicine, v. 1, n. 9 , p.1-8, 2005.

GUERRA, F. Origen de las epidemias en la conquista de América. Quinto centenario, v. 14, p.43-51, 1988.

HANAZAKI, N.; et al. Diversity of plant uses in two Caiçara communities from the Atlantic Forest coast, Brazil. Biodiversity and Conservation, v. 9, p.597-615, 2000.

HANAZAKI, N.; et al. Indigenous and traditional knowledge, sustainable harvest, and the long road ahead to reach the 2020 Global Strategy for Plant Conservation objectives. Rodriguesia, v. 69, n. 4, p.1587-1601, 2018.

JOÃO, I. F.; et al. As plantas e os conhecimentos tradicionais no tratamento de doenças na comunidade indígena da Aldeia Panambi-Douradina-MS. In: SANGALLI, A.; LADEIA, E. S.; BENITES, E.; PEREIRA, V. Z. (Orgs.). Tekoha Ka'aguy: Diálogos entre saberes Guarani e Kaiowá e o ensino de Ciências da Natureza. Jundiaí: Paco Editorial, 2017 , v. 1, p. 55-81.

KING, S. R.; TEMPESTA, M. S. From shaman to human clinical trials: The role of industry in ethnobotany, conservation, and community reciprocity. In: DEREK J. CHADWICK J. M. (Orgs.). Ethnobotany and the search for new drugs, 1994. p. 197-213. 
KOPENAWA, D.; ALBERT, B. A queda do céu. Palavras de um xamã Yanomami. São Paulo: Companhia das Letras, 2015.

KRENAK, A. Paisagens, territórios e pressão colonial. Espaço Ameríndio, v. 9, n. 3, p.327-343, 2015.729p. KRENAK, A. Pensando com a cabeça na Terra. In: REUNIÃO DE ANTROPOLOGIA DA CIÊNCIA E TECNOLOGIA, 6, 2017, São Paulo. Anais da React... São Paulo: Unicamp: Unicamp, 2017. p. 1-11.

LANA, R. M.; et al. Emergência do novo coronavírus (SARS-CoV-2) e o papel de uma vigilância nacional em saúde oportuna e efetiva. Cadernos Saúde Pública, v. 36, n. 3, e00019620, 2020.

LÉVI-STRAUSS, C. Tristes Trópicos. Paris: Plon, 1955.456p.

LIU, J.; et al. Longitudinal characteristics of lymphocyte responses and cytokine profiles in the peripheral blood of SARS-CoV-2 infected patients, medRxiv. EBioMedicine, v. 55, p. 1-2, 2020.

LOPES, J. M.; et al. O conhecimento tradicional e o uso de plantas medicinais por mulheres indígenas da aldeia Jaguapiru. In: SANGALLI, A; LADEIA, E. S.; BENITES, E.; PEREIRA, V. Z. (Orgs.). Tekoha Ka'aguy: Diálogos entre saberes Guarani e Kaiowá e o ensino de Ciências da Natureza. Jundiaí: Paco Editorial, 2017, v. 1, p. 41-53.

LUO, H.; et al. Can Chinese medicine be used for prevention of corona virus disease 2019 (COVID-19)? A review of historical classics, research evidence and current prevention programs. Chinese journal of Integrative Medicine, p. 1-8, 2020.

MARANHÃO, R. A. Os cientistas sociais no combate ao coronavírus e contra a necropolítica: primeiras batalhas. Boletim de Conjuntura (BOCA), v. 2, n. 5, p.1-14, 2020.

MARCOLINO, T. Q.; MIZUKAMI, M. G. N. Narrativas, processos reflexivos e prática profissional: apontamentos para a pesquisa e formação. Interface Comum, v. 12, n. 26, p.541-547, 2008.

MARTINS, L.; LAGO, A. A. D. Conservação de semente de Cedrela fissilis: teor de água da semente e temperatura do ambiente. Revista Brasileira de Sementes, v. 30, n.1, p.161-167, 2008.

MBEMBE, A. Necropolítica: biopoder, estado de exceção, política da morte. São Paulo: n-1 edições, 2018. 80p.

MELIÀ, B. El Guaraní Conquistado y Reducido: ensaios de etnohistoria 4ạ ed. Asunción: CEADUC - Centro de Estudios Antropológicos, 1997. 301p.

MELLO, L. T. A. D.; et al. Estudo da sazonalidade e distribuição espaço-temporal das chuvas no bioma da Mata Atlântica do estado do Mato Grosso do Sul. In: SIMPÓSIO BRASILEIRO DE SENSORIAMENTO REMOTO, 15, 2011, Curitiba. Anais do Simpósio... Curitiba: INPE, 2011. p. 4452-4459.

MILLION, J. L. Estudo etnobotânico na comunidade de Taquara: a luta pelo uso de plantas nativas pelo povo Kaiowá, MS, Brasil. 2017. Dissertação (Mestrado em Botânica) - Universidade de Brasília, DF, 2017.

MORS, W. B.; et al. Medicinal Plants of Brazil.

Michigan: Reference Publications Inc., 2000. 60 p.

MOвOT, Missouri Botanical Garden. Disponível em: https://www.missouribotanicalgarden.org/plantfinder/plantfindersearch.aspx > Acesso em: 28 ago. 2020.

MOTA, J. G. B. Territórios de resistência e práticas descoloniais: estratégias de luta Guarani e Kaiowá pelo Tekoha-Mato Grosso do Sul/Brasil. Campo Território: Revista de Geografia Agrária, v. 10, n. 20, p.416-439, 2015. OLIVEIRA, F. C. D.; et al. Advances in ethnobotany research in Brazil. Acta botânica brasílica, v. 23, n. 2, p.590605, 2009.

ORGANIZAÇÃO MUNDIAL DA SAÚDE OMS (WHO). International Statistical Classification of Diseases and Related Health Problems, 10th Revision. 2006.

PAULILO, M. T. S.; et al. Responses to light changes in tropical seedlings of the Brazilian Atlantic rainforest tree species Cecropia glazioui (Cecropiaceae) and Cedrela fissilis (Meliaceae). Australian Journal of Botany, v. 55, n. 8, p.795-802, 2008.

PEREIRA, Z. V.; et al. Medicinal plants used by Ponta Porã community, Mato Grosso do Sul state. Acta Scientiarum. Biological Sciences, v. 31, n. 3, p.293-299, 2009.

PEREIRA, Z. V.; FERNANDES, S. S. L.; SANGALLI, A.; MUSSURY, R. M. Usos múltiplos de espécies nativas do bioma Cerrado no Assentamento Lagoa Grande, Dourados, Mato Grosso do Sul. Revista Brasileira de Agroecologia, v. 7, n. 2, p.126-136, 2012.

PEREIRA, L. M. Demarcação de terras kaoiwa e guarani em MS: ocupação tradicional, reordenamentos organizacionais e gestão territorial. Tellus, n. 18, p.115-137, 2014.

PEREIRA, L.M. Os kaiowá em Mato Grosso do Sul: módulos organizacionais e humanização do espaço habitado. Dourados: UFGD, 2016. 196p.

PESSATTO, L. R.; et al. Exposição materna à Moquiniastrum polymorphum subsp. Floccosum causa aborto, danos no DNA e comprometem o desenvolvimento gestacional. Perspectivas Experimentais e Clínicas, Inovações Biomédicas e Educação em Saúde (PECIBES), v. 1, n. 1., p. 1, 2015.

PORTO-GONÇALVES, Carlos Walter. A Reinvenção dos Territórios: a experiência latino-americana e caribenha. In: CECEÑA, A. E. (Org.). Los desafíos de las emancipaciones en un contexto militarizado, Buenos Aires: CLACSO, 2006, p.151-197.

POSEY, D. A. Etnobiologia: teoria e prática. In: RIBEIRO, D. (Org.). Suma etnológica brasileira, 1987, p. 15-25. 
PRADO, A. C. C.; et al. Etnobotânica como subsídio à gestão socioambiental de uma unidade de conservação de uso sustentável. Rodriguésia, v. 70, n. 1, p.1-10, 2019.

RAMOS, A. R. O papel político das epidemias: o caso Yanomami. Brasília: Departamento de Antropologia, 1993. 21p.

REGO, F. L. H.; et al. Recursos genéticos, biodiversidad, conocimiento tradicional Kaiowá y Guarani y el desarrollo local. Interações, v. 11, n. 1, p.55-69, 2010.

RIBEIRO, D. Convívio e contaminação. Efeitos dissociativos da população provocada por epidemias em grupos indígenas. Sociologia, v. 18, n. 1, p.3-50, 1956.

RIBEIRO, D. Os índios e a civilização: a integração das populações indígenas no Brasil moderno. Petrópolis: Vozes. 1982, 510p.

RODRIGUES, E. Plants and animals utilized as medicines in the Jau National Park (JNP), Brazilian Amazon. Phytotherapy Research, v. 20, p.378-391, 2006.

RODRÍGUEZ-SILVA, C.; et alS. Agracejo: Muchas especies, escasa información etnobotánica y etnofarmacológica. Ethnobotany Research and Applications, v. 19, p.1-12, 2020.

RULLI, M. C.; et al. The nexus between forest fragmentation in Africa and Ebola virus disease outbreaks. Scientific reports, v. 7, p.1-8, 2017.

RUIZ-SAENZ, J.; et al. Brazil burning! What is the potential impact of the Amazon wildfires on vector-borne and zoonotic emerging diseases? A statement from an international experts meeting. Travel medicine and infectious disease, v. 31, p.37-52, 2019.

SANCHO, G. Revisión Y filogenia de la sección Moquiniastrum Cabrera del género Gochnatia Kunth (Asteraceae, Mutisieae). Fontqueria, v. 54, p.61-122, 2000.

SANTOS, A.B. Colonização, quilombos: modos e significações. Brasília: Instituto de Inclusão no Ensino Superior e na Pesquisa, 2015. 150p.

SANTOS, A.B. Somos da terra. Piseagrama, v.7, n. 12, p.44-51, 2018.

SANTOS, D. L.; et al. Saberes tradicionais sobre plantas medicinais na conservação da biodiversidade amazônica. Ciências em Foco, v. 12, n. 1, p.86-95, 2019.

SEHGAL, R. N. M. Deforestation and avian infectious diseases. Journal of experimental biology, v. 213, n. 6, p.955960, 2010.

SERAGUZA, L. O. O. S. Cosmos, corpos e mulheres Kaiowa e Guarani de aña à kuña. 2013. Dissertação (Mestrado em Antropologia) - Universidade Federal da Grande, Dourados, 2013.

SILVA, J. G.; et al. Are medicinal plants an alternative to the use of synthetic pharmaceuticals in animal healthcare in the Brazilian semi-arid? Ethnobotany Research and Applications, v. 19, p.1-20, 2020.

SHIVA, V. Biopirataria: a pilhagem da natureza e do conhecimento. Petrópolis: Vozes, 2001.152p.

SHIVA, V. Monoculturas da mente: perspectivas da biodiversidade e da biotecnologia. São Paulo: Gaia, 2003. 240p.

SOLDATI, G. T.; BARROS, F. The COVID-19 pandemic and future of ethnobiology. Ethnobiology and Conservation, v. 9, p.1-4, 2020.

THUY, B. T. P.; et al. Investigation into SARS-CoV-2 Resistance of Compounds in Garlic Essential Oil. ACS Omega, v. 5, n. 14, p.8312-8320, 2020.

TOMCHINSKY, B.; et al. Publicações científicas das etnociências-caminhos passados e futuros. Ethnoscientia, v. 4, n.1, p. 1-16, 2019.

UJVARI, S. C. A história da disseminação dos microrganismos. Estudos Avançados, v. 22, n. 64, p.171-182, 2008.

UZAR, I.; UZAR, F. Traditional medicinal plants used for the treatment of viral infections: A short review. Bütünleyici ve Anadolu Tıbbı Dergisi, v. 1, n. 2, p.29-48, 2020.

VALIENTE, C. A. Modos de produção de coletivos Kaiowá na situação atual da Reserva Indígena de Amambai, MS. 2019. Dissertação (Mestrado em Antropologia) - Faculdade de Ciências Humanas, Universidade Federal da Grande Dourados, Dourados, 2019.

VIETTA. K. Histórias sobre as terras e xamãs kaiowa: territorialidade e organização social na perspectiva dos kaiowa de Panambizinho (Dourados, MS) após 170 anos de exploração e povoamento não indígena da faixa de fronteira entre o Brasil e Paraguai. 2007. Tese (Doutorado em Antropologia Social) -Universidade de São Paulo, São Paulo, 2007.

VIVEIROS DE CASTRO, E. A inconstância da alma selvagem e outros ensaios de antropologia. São Paulo: Cosac \& Naify, 2002. 430p.

WOLFE, N. D.; et al. Bushmeat hunting, deforestation, and prediction of zoonotic disease. Emerging infectious diseases, v. 11, n. 12, p.1822, 2005.

ZOA-ASSOUMOU, S.; et al. Chikungunya Virus: A Brief Review of the Thematic. In: Emerging and Reemerging Viral Pathogens. Academic Press, v. 47, p.241-252, 2020. 